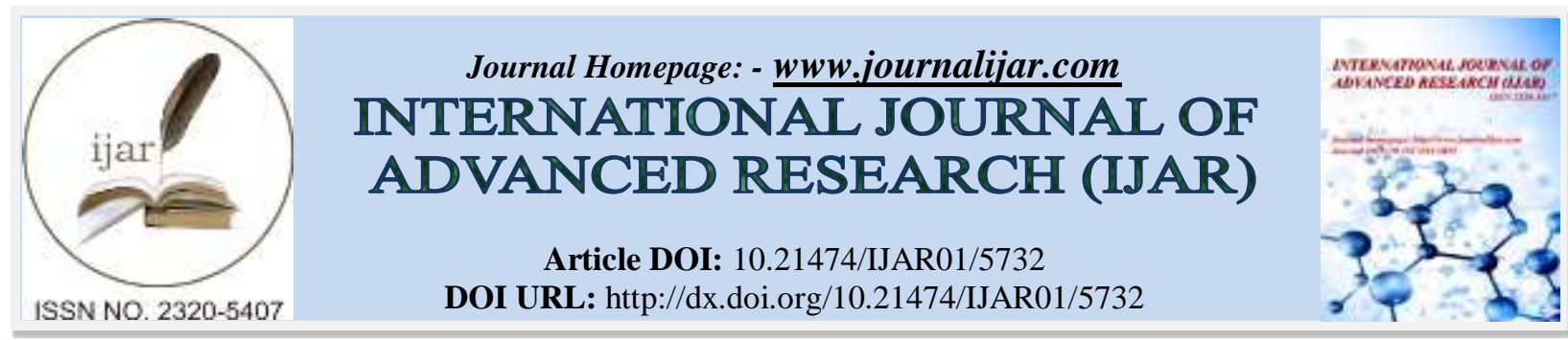

RESEARCH ARTICLE

\title{
ROLE OF CORPORATE SOCIAL RESPONSIBILITY (CSR): AN EFFORT TO SECTORAL ANALYSIS OF DAY OF THE WEEK EFFECT IN INDIAN STOCK MARKET.
}

\author{
B. Velmurugan ${ }^{1}$, RP. Nivethigha ${ }^{2}$ and C. Gnanaprakasam ${ }^{3}$. \\ 1. B Velmurugan, (PhD-CB-DEC2013-0933), Research Scholar, Bharathiar University, Coimbatore, Asst \\ Professor, Department of MBA, NPR College of Engineering and Technolgoy, Dindigul, Tamilnadu. \\ 2. RP Nivethigha, Full Time Research Scholar, Anna University Chennai. \\ 3. C Gnanaprakasam, Prinicpal/Director, Agni School of Business Excellence, Dindigul, Tamilnadu, India.
}

\section{Manuscript Info}

Manuscript History

Received: 01 September 2017

Final Accepted: 03 October 2017

Published: November 2017

Key words:-

Indices, Returns, Periodic Analysis,

Highest Average Return, Descriptive

Statistics and Random Walk Theory.

\begin{abstract}
The learning explore whether the anomalous day of the week effect is found in Indian stock market. The data used for the study is the most important sectoral indices of the national stock exchange for the time 2006 to 2016. Descriptive statistics, correlation, regression in SPSS are useful to check whether the implication of the day of the week result is there in Indian stock market. The suggestion is that the day of the week outcome is there - it is examined during that Wednesdays have acquiesced the maximum average return; regression and correlation inspect that return for all the days of the week is not identical. Therefore the instability subsists among stocks. Hence it confirms the random walk theory and admits the efficient market theory. These results suggest attractive prospects for the financier to set offer/inquire instructions in order to make the most of the profits. Intermittent examination requests to be implement so that financier can attain irregular profits.
\end{abstract}

Copy Right, IJAR, 2017,. All rights reserved.

\section{Introduction:-}

Corporate social responsibility is a thought that has develop into fairly common in the world-of-business today. The present-day commencement of corporate social responsibility (CSR) involves that business willingly incorporate societal and environmental apprehension in their process and relations with shareholders. CSR entails relate the idea of sustainable growth to the business world. Corporation that esteem and pay attention to their shareholders should obviously be alarmed by their development and prosperity, but they should also be conscious of the profitable, environmental, social and societal effect of their actions. Too frequently, attain corporate social responsibility is understood from the viewpoint of business liberality to the public projects and helpful contributions, but this not succeed to detain the majority expensive offerings that a company has to formulate. In broad sense social responsibility is seen as the statement of association to show a missionary rather than a mercenary approach to the culture or situation in which they function. Today, CSR in India has vanished ahead of simply 'contributions and donations' and is move towards in a more planned manner. It has suited a vital part of the business strategy (Das Gupta 2010). These days companies have turn into more translucent in their balance sheet. They are integrating their corporate social responsibility schemes in their yearly report. Companies have CSR squads that create exact 
guidelines, plan and objectives for their CSR programs and set aside financial statement to maintain them. Companies in India have fairly been positive in taking up CSR schemes and incorporating them in their business practices.

\section{Day of the Week Effect in Indian Stock Market:-}

In modern years the testing of market difference in stock return has turn into an dynamic field of investigation in pragmatic investment and has been getting enormous consideration. Among the more well known difference are the size effect, the January effect, the day of the effect. The main cause of these variations is the change in the environment. For example, sales of ice creams generally increase in summer season. Besides this customs and tradition also affect economic variables for instance sales of crackers increase during diwali season. Similarly stock returns reveal organized model at certain times of the day, week or month. The subsistence of seasonality in stock returns however infringe an essential assumption in finance called the efficient market hypothesis.

The market efficiency manipulate the savings approach for the investors because in an efficient market, there would be no underrate or overrated stocks. The existence of seasonality contravene the market efficiency because equity prices are no longer based on the past model, its varying randomly. This assist the market contributor to adjust their trading plan which could acquire reasonable profits. For example if there is an proof of day of the week effect investors can formulate a trading plan of selling securities on Friday and buying on Mondays in order to make surplus fair earnings.

There are a few reasons for the day of the week effect. In some market Monday recorded higher return; in another market it recorded fewer return. The reason is that Monday is the day with the lowly trading volume and in which the tendency of the individuals to carry out is high relative to other days of the week and that of the organizations to sell on Monday is higher than their tendency to purchase and the other reason is the defrayal cost-there are five trading days in stock market. If the investors buy on Wednesday's closing price and sell on Thursdays closing price then the investor will earn higher return on Thursday. so it is forever possible to uncover anomalous returns for short duration, but it matter hard to create high returns for long duration and that it posses the market efficiency. Using descriptive statistics such as mean, standard deviation, correlation, regression this study means to discover day of the week effect in Indian stock market

\section{Need for the Study:-}

Efficient market can instantly process the information and it will be revealed on securities values. This information make sure that the stock returns across all the days of the weeks and months are identical. For that reason the market participant cannot be able to earn anomalous earnings.

It is significant that there are disparity in instability of stock returns by the day of the week effect, month of the year. If the investor can recognize the difficulty in instability, then it would be easier to make investment decision based on both return and risk. This study is to observe day of the week effect in 7 segments in Indian stock market.

\section{Objectives of the Study:-}

\section{The following are the objectives of this study}

$>$ To study the day of the week effect in corporate social responsibility on Indian stock market

$>$ To examine the consequences of daily return of seven foremost segments in Indian stock market there by representing the occurrence of chance to make unswerving anomalous returns through a trading approach of buying on Mondays and selling on Fridays

\section{Scope of the Study:-}

The main scope of this study is to examine the market movements; It also assist to frame the particular trading rule for the investors to gain anomalous returns from Indian markets. This study explored that on Wednesdays return of automobile sectors, Information technology sector, Metal sectors are higher than the other sectors and also using correlation and regression, returns of all the days of the week are not correlated and not equal. Hence it would be an appropriate strategy to find out day on which share could be bought or sold. 


\section{Limitations:-}

The major drawback in this study is there is not only the business news affect the Indian market efficiency. There are different number of primary factors influencing more and thus affect market efficiency. Thus investor cannot rely on single strategy to obtain the anomalous returns. Only by keep on focus the market movements he can hope up with the recent news and then he can buy/sell their shares according to the market movements. Using SPSS 20.0 only data were analyzed there is difference obtained when the results were created between descriptive statistics and correlation \& regression. So depending up on this software only investor's strategy could not be framed

\section{Research Methodology:-}

This type of study comes under analytical research, because it is a data based research, comes up with conclusions which are capable of being confirmed by interpretation and experimentation. It is necessary to structure the hypothesis and then works to get enough facts to confirm or controvert the hypothesis. This type of empirical research is suitable when proof is sought that certain variables influence other variables in some way.

\section{Primary data:-}

There is no primary data collection method is used for this study.

\section{Secondary data}

For this purpose of this study NSE NIFTY INDEX is considered to study the problem. The daily closing price value is collected from NSE website of seven sectors from the period 2006 to 2016.

Table 1:- AUTO index 2006-2017

\begin{tabular}{|l|l|l|l|l|l|l|l|l|l|}
\hline & $\mathbf{N}$ & Minimum & Maximum & Mean & $\begin{array}{l}\text { Std. } \\
\text { Deviation }\end{array}$ & \multicolumn{2}{|l|}{ Skewness } & \multicolumn{2}{l|}{ Kurtosis } \\
\cline { 2 - 10 } & Statistic & Statistic & Statistic & Statistic & Statistic & Statistic & $\begin{array}{l}\text { Std. } \\
\text { Error }\end{array}$ & Statistic & $\begin{array}{l}\text { Std. } \\
\text { Error }\end{array}$ \\
\hline $\begin{array}{l}\text { Monday } \\
\text { return }\end{array}$ & 1823 & -.096 & 1.0018 & .000607 & .0250271 & 35.19 & .057 & 1408.1 & .115 \\
\hline $\begin{array}{l}\text { Tuesday } \\
\text { return }\end{array}$ & 1779 &.- .456 & .0576 & -.00051 & .0153632 & -19.96 & .058 & 536.52 & .116 \\
\hline $\begin{array}{l}\text { Wednesday } \\
\text { return }\end{array}$ & 1976 & -.058 & .5714 & .000468 & .0145752 & 30.44 & .055 & 1194.0 & .110 \\
\hline $\begin{array}{l}\text { Thursday } \\
\text { return }\end{array}$ & 1975 & -.075 & .0663 & .00006 & .0071506 & -.977 & .055 & 24.804 & .110 \\
\hline $\begin{array}{l}\text { Friday } \\
\text { return }\end{array}$ & 1972 & -6.892 & .0662 & -.00311 & .1554080 & -44.24 & .055 & 1962.2 & .110 \\
\hline $\begin{array}{l}\text { ValidN } \\
\text { (listwise) }\end{array}$ & 1771 & & & & & & & & \\
\hline
\end{tabular}

Table illustrates the descriptive statistics analysis for auto sectors from the period 2006 to 2016. For that the variables are Monday return, Tuesday return, Wednesday return, Thursday return, Friday return, consequent statistics such as mean, standard deviation, skewness, kurtosis. This analysis confirms that, on average Wednesday returns are higher than all other days of the return. Standard deviation is also higher for Wednesday return than all other days of the return, signifying that Wednesday returns are variable than returns of Monday, Tuesday, Thursday \& Wednesday. Monday, Thursday and Friday were negatively skewed and all other days were positively skewed. Contrast the numerical value with twice the standard error and include the range from positive value to negative value. If the value lies within the range then the distribution is normal otherwise it is not normal distribution. Here no other value is within this range, so it is come under in the non normal distribution. It means that the dispersion of possible rates of return for all the days is not nearer to zero for all the days except Monday, Thursday and Friday. It shows that there is day of the week effect continue in auto mobile sectors except Monday, Thursday and Friday. Kurtosis value for all the days of the week is positive. This indicates that the distribution is flatter than normal distribution. 
Table 2:- BANK index 2006-2017

\begin{tabular}{|l|l|l|l|l|l|l|l|l|l|}
\hline & N & Minimum & Maximum & Mean & $\begin{array}{l}\text { Std. } \\
\text { Deviati }\end{array}$ & \multicolumn{2}{l|}{ Skewness } & \multicolumn{2}{l|}{ Kurtosis } \\
\cline { 2 - 9 } & Statistic & Statistic & Statistic & Statistic & Statistic & Statistic & $\begin{array}{l}\text { Std. } \\
\text { Error }\end{array}$ & $\begin{array}{l}\text { Statistic } \\
\begin{array}{l}\text { Std. } \\
\text { Error }\end{array}\end{array}$ \\
\hline $\begin{array}{l}\text { Monday } \\
\text { return }\end{array}$ & 2656 & -.0879 & .1723 & .00006 & .0010525 & .877 & .048 & 47.07 & .095 \\
\hline $\begin{array}{l}\text { Tuesday } \\
\text { return }\end{array}$ & 2656 & -.0877 & .0744 & .00005 & .0087940 & -.131 & .048 & 22.59 & .095 \\
\hline $\begin{array}{l}\text { Wednesday } \\
\text { return }\end{array}$ & 2665 & -.1384 & .0906 & .0002 & .0091060 & -.438 & .047 & 37.88 & .095 \\
\hline $\begin{array}{l}\text { Thursday } \\
\text { return }\end{array}$ & 2662 & -.1513 & .0672 & .00012 & .0091116 & -1.540 & .047 & 43.09 & .095 \\
\hline $\begin{array}{l}\text { Friday } \\
\text { return }\end{array}$ & 2673 & -.1348 & .1140 & .00017 & .009715 & -.237 & .047 & 32.93 & .095 \\
\hline $\begin{array}{l}\text { Valid N } \\
\text { (listwise }\end{array}$ & 2620 & & & & & & & & \\
\hline
\end{tabular}

For banking sector, the average of Thursday returns is higher than that of all other days of return. Standard deviation value is also slightly higher for Thursday than other days. So in this sector Thursday is variable than all other days. Tuesday, Wednesday, Thursday, Friday were negatively skewed and Monday was positively skewed. Contrast the numerical value with twice the standard error and comprise the range from positive value to negative value. If the value lies within the range then the distribution is normal otherwise it is not normal distribution. Here all values were within this range, so it comes under the normal distribution. It means that the dispersion of possible rates of return for all the days is nearer to zero for all the days of the week. It demonstrates that there is no day of the week effect in banking sector. Kurtosis value for all the days of the week is positive. This shows that the distribution is flatter than normal distribution.

Table 3- FINANCE index 2004-2017

\begin{tabular}{|c|c|c|c|c|c|c|c|c|c|}
\hline & \multirow{2}{*}{$\begin{array}{l} \\
\text { Statistic }\end{array}$} & \multirow{2}{*}{$\begin{array}{l}\text { Minimum } \\
\text { Statistic }\end{array}$} & \multirow{2}{*}{$\begin{array}{l}\text { Maximum } \\
\text { Statistic }\end{array}$} & \multirow{2}{*}{$\begin{array}{l}\text { Mean } \\
\text { Statistic }\end{array}$} & \multirow{2}{*}{$\begin{array}{l}\text { Std. } \\
\text { Deviation } \\
\text { Statistic }\end{array}$} & \multicolumn{2}{|l|}{ Skewness } & \multicolumn{2}{|l|}{ Kurtosis } \\
\hline & & & & & & Statistic & $\begin{array}{l}\text { Std. } \\
\text { Error }\end{array}$ & Statistic & $\begin{array}{l}\text { Std. } \\
\text { Error }\end{array}$ \\
\hline $\begin{array}{l}\text { Monday } \\
\text { return }\end{array}$ & 1952 & -.0939 & .1780 & .00010 & .00011 & 1.197 & .055 & 52.277 & .111 \\
\hline $\begin{array}{l}\text { Tuesday } \\
\text { return }\end{array}$ & 1958 & -.0754 & .0827 & .000103 & .00881 & .009 & .055 & 22.487 & .111 \\
\hline $\begin{array}{l}\text { Wednesday } \\
\text { return }\end{array}$ & 1969 & -.1213 & .0940 & .000126 & .00927 & -.435 & .055 & 32.653 & .110 \\
\hline $\begin{array}{l}\text { Thursday } \\
\text { return }\end{array}$ & 1962 & -.1441 & .0662 & .000083 & .00937 & -1.917 & .055 & 42.863 & .110 \\
\hline $\begin{array}{l}\text { Friday } \\
\text { return }\end{array}$ & 1967 & -.1260 & .1193 & .000212 & .0001 & .114 & .055 & 34.687 & .110 \\
\hline $\begin{array}{l}\text { Valid } \\
\text { (listwise) }\end{array}$ & 1934 & & & & & & & & \\
\hline
\end{tabular}

This table shows that on average Tuesday return is higher than all other days of return. Standard deviation of Tuesday is also higher that all other days. So Tuesday is variable for finance sector. Wednesday, Thursday were negatively skewed and Monday, Tuesday, Friday was positively skewed. Compare the numerical value with twice the standard error and include the range from positive value to negative value. If the value lies within the range then the distribution is normal otherwise it is not normal distribution. Here only Tuesday value was within this range, so it comes under normal distribution. And Wednesday, Thursday were negatively skewed and it is also does not lies within this range. It means that the dispersion of possible rates of return for all the days is nearer to zero for Wednesday, Thursday .It illustrates that there is day of the week effect in finance sector except Wednesday and Thursday. Kurtosis value for all the days of the week is positive. This point out that the distribution is flatter than normal distribution 
Table 4:- FMCG index 2006-2017

\begin{tabular}{|c|c|c|c|c|c|c|c|c|c|}
\hline & $N$ & Minimum & Maximum & Mean & $\begin{array}{l}\text { Std. } \\
\text { Deviation }\end{array}$ & Skewnes & & Kurtosis & \\
\hline & Statistic & Statistic & Statistic & Statistic & Statistic & Statistic & $\begin{array}{l}\text { Std. } \\
\text { Error }\end{array}$ & Statistic & $\begin{array}{l}\text { Std. } \\
\text { Error }\end{array}$ \\
\hline $\begin{array}{l}\text { Monday } \\
\text { return }\end{array}$ & 2656 & -.0715 & .0830 & .000047 & .0067961 & -.269 & .048 & 29.017 & .095 \\
\hline $\begin{array}{l}\text { Tuesday } \\
\text { return }\end{array}$ & 2656 & -.0851 & .0498 & .000118 & .0061111 & -.880 & .048 & 28.978 & .095 \\
\hline $\begin{array}{l}\text { Wednesday } \\
\text { return }\end{array}$ & 2665 & -.0522 & .0626 & .000193 & .0060802 & 1.211 & .047 & 23.879 & .095 \\
\hline $\begin{array}{l}\text { Thursday } \\
\text { return }\end{array}$ & 2662 & -.1238 & .0621 & .000016 & .0064984 & -2.710 & .047 & 66.433 & .095 \\
\hline $\begin{array}{l}\text { Friday } \\
\text { return }\end{array}$ & 2673 & -.0624 & .0754 & .00008 & .0064363 & .377 & .047 & 29.844 & .095 \\
\hline $\begin{array}{ll}\text { Valid } & N \\
\text { (listwise) } & \\
\end{array}$ & 2620 & & & & & & & & \\
\hline
\end{tabular}

For FMCG, mean value for Tuesday is higher than all other days. Likewise it has slightly higher value of standard deviation than all other days of return. So Tuesday is variable than all other days. Monday, Tuesday, Thursday, were negatively skewed and other days were positively skewed. Compare the numerical value with twice the standard error and take account of the range from positive value to negative value. If the value lies within the range then the distribution is normal otherwise it is not normal distribution. Here no other value falls within this range, so it is not come under normal distribution, and Monday, Tuesday, Thursday were negatively skewed and it is also does not fall within this range. It means that the dispersion of possible rates of return for all the days is nearer to zero for Monday, Tuesday, Thursday. It shows that there is day of the week effect in media sector except Monday, Tuesday, and Thursday. Kurtosis value for all the days of the week is positive. This shows that the distribution is flatter than normal distribution.

Table 5 - IT index 2006-2017

\begin{tabular}{|l|l|l|l|l|l|l|l|l|l|}
\hline & N & Minimum & Maximum & Mean & $\begin{array}{l}\text { Std. } \\
\text { Deviation }\end{array}$ & \multicolumn{2}{|l|}{ Skewness } & \multicolumn{2}{l|}{ Kurtosis } \\
\cline { 2 - 9 } & Statistic & Statistic & Statistic & Statistic & Statistic & Statistic & Std. & Statistic & Std. \\
\hline $\begin{array}{l}\text { Monday } \\
\text { return }\end{array}$ & 2662 & -.3115 & .12492 & -.00012 & .0123400 & -6.170 & .047 & 176.0 & .095 \\
\hline $\begin{array}{l}\text { Tuesday } \\
\text { return }\end{array}$ & 2662 & -.1438 & .10736 & .000074 & .0103203 & -.641 & .047 & 42.03 & .095 \\
\hline $\begin{array}{l}\text { Wednesday } \\
\text { return }\end{array}$ & 2662 & -.1719 & .21599 & .000304 & .0112871 & 2.770 & .047 & 92.34 & .095 \\
\hline $\begin{array}{l}\text { Thursday } \\
\text { return }\end{array}$ & 2662 & -.2212 & .10151 & .000051 & .0115296 & -3.294 & .047 & 75.40 & .095 \\
\hline $\begin{array}{l}\text { Friday } \\
\text { return }\end{array}$ & 2662 & -.1385 & .11867 & -.00020 & .0108061 & -1.334 & .047 & 36.70 & .095 \\
\hline $\begin{array}{l}\text { Valid N } \\
\text { (listwise }\end{array}$ & 2662 & & & & & & & & \\
\hline
\end{tabular}

For IT sectors, Wednesday return is higher than other days of the return. Likewise standard deviation is also higher for Wednesday. This shows that Wednesday is variable for this sector. Monday, Tuesday, Thursday, Friday were negatively skewed and other days were positively skewed. Match up the numerical value with twice the standard error and include the range from positive value to negative value. If the value lies within the range then the distribution is normal otherwise it is not normal distribution. Here no other value was within this range, so it does not come under normal distribution. And Monday, Tuesday, Thursday, Friday were negatively skewed and it is also does not fall within this range. It means that the dispersion of possible rates of return for all the days is nearer to zero for Monday, Tuesday, Thursday, Friday. 
It indicates that there is day of the week effect in information technology sector except Monday, Tuesday, Thursday, and Friday. Kurtosis value for all the days of the week is positive. This indicates that the distribution is flatter than normal distribution.

\section{Correlation - Auto Mobile Index Correlation:-}

H0: There is no significant correlation between the returns secured by AUTO index on various days of the week H1: There is a significant correlation between the returns secured by AUTO index on various days of the week.

Table 6:- Index Correlation

\begin{tabular}{|c|c|c|c|c|c|c|}
\hline & & $\begin{array}{l}\text { Monday } \\
\text { return }\end{array}$ & $\begin{array}{l}\text { Tuesday } \\
\text { return }\end{array}$ & $\begin{array}{l}\text { Wednesday } \\
\text { return }\end{array}$ & $\begin{array}{l}\text { Thursday } \\
\text { return }\end{array}$ & $\begin{array}{l}\text { Friday } \\
\text { return }\end{array}$ \\
\hline \multirow[t]{2}{*}{$\begin{array}{l}\text { Monday } \\
\text { return }\end{array}$} & $\begin{array}{l}\text { Pearson } \\
\text { Correlation }\end{array}$ & 1 & -.002 & .000 & .000 & .001 \\
\hline & Sig. (2-tailed) & & .948 & .989 & .988 & .982 \\
\hline \multirow[t]{2}{*}{$\begin{array}{l}\text { Tuesday } \\
\text { return }\end{array}$} & $\begin{array}{l}\text { Pearson } \\
\text { Correlation }\end{array}$ & -.002 & 1 & .001 & .000 & .000 \\
\hline & Sig. (2-tailed) & .948 & & .963 & .984 & .998 \\
\hline \multirow[t]{2}{*}{$\begin{array}{l}\text { Wednesday } \\
\text { return }\end{array}$} & $\begin{array}{l}\text { Pearson } \\
\text { Correlation }\end{array}$ & .000 & .001 & 1 & .000 & .001 \\
\hline & Sig. (2-tailed) & .989 & .963 & & .985 & .977 \\
\hline \multirow[t]{2}{*}{$\begin{array}{l}\text { Thursday } \\
\text { return }\end{array}$} & $\begin{array}{l}\text { Pearson } \\
\text { Correlation }\end{array}$ & .000 & .000 & .000 & 1 & .000 \\
\hline & Sig. (2-tailed) & .988 & .984 & .985 & & .990 \\
\hline \multirow[t]{2}{*}{$\begin{array}{l}\text { Friday } \\
\text { return }\end{array}$} & $\begin{array}{l}\text { Pearson } \\
\text { Correlation }\end{array}$ & .001 & .000 & .001 & .000 & 1 \\
\hline & Sig. (2-tailed) & .982 & .998 & .977 & .990 & \\
\hline
\end{tabular}

At the $\alpha=0.05$ level of significance, There is a no significant correlation between the returns secured by AUTO index on various days of the week

Regression - Bank Index Regression Analysis:-

H0: The return of BANK index is not significantly influenced by day of the week effect

H1: The return of BANK index is significantly influenced by day of the week effect

Table 7- Bank Index - Model Summary

\begin{tabular}{|c|c|c|c|c|c|c|c|c|}
\hline \multirow[t]{2}{*}{$\boldsymbol{R}$} & \multirow{2}{*}{$\begin{array}{l}\text { R } \\
\text { Square }\end{array}$} & \multirow{2}{*}{$\begin{array}{l}\text { Adjusted } \\
R \\
\text { Square }\end{array}$} & \multirow{2}{*}{$\begin{array}{lr}\text { Std. Error } \\
\text { of the } \\
\text { Estimate }\end{array}$} & & \multicolumn{3}{|c|}{ Change Statistics } & \multirow[b]{2}{*}{$\begin{array}{l}\text { Sig. } F \\
\text { Change }\end{array}$} \\
\hline & & & & $\begin{array}{l}\text { R Square } \\
\text { Change }\end{array}$ & F Change & $d f 1$ & $d f 2$ & \\
\hline .057 & .003 & .001 & .021123116 & .003 & 1.757 & 5 & 2664 & .118 \\
\hline
\end{tabular}

This table is second-hand to examine how the needy variable is prejudiced by selfgoverningvariable .in bank index ( $\mathrm{r}$ square $=0.003$ ), self-governing variable pressure the dependent variable only by $0.3 \%$.so the income are not uneven bottom on the day of the week.

This demonstrates that the marketplace is informational well-organized

Table 8:- Bank Index - Anova

\begin{tabular}{|l|l|l|l|l|l|l|}
\hline \multirow{3}{*}{1} & Model & Sum of Squares & Df & Mean Square & F & Sig. \\
\cline { 2 - 7 } & Regression & .004 & 5 & .001 & 1.757 & $.118^{a}$ \\
\cline { 2 - 7 } & Residual & 1.189 & 2664 & .000 & & \\
\cline { 2 - 6 } & Total & 1.193 & 2669 & & & \\
\end{tabular}

This table helps to examine whether the regression is valid or not. If the significance value is less than 0.05 , it is interpreted that the regression is valid. If the significance value is greater than 0.05 then the regression is not valid. Here the BANK index is not significant which means that the there is no change in the daily return due to corporate information disclosure and this shows the market efficiency. 
In order to check the significance using this table, It is significant to check the unstandardized coefficient is close to zero and significance values are greater than zero. Similarly here the unstandardized coefficient is close to zero and significance values are greater than zero It is obliged to accept null hypothesis.

Such as the return of BANK index is not significantly influenced by day of the week effect. Moreover the value of beta is the measure of risk, if the value increases then there is a more occurrence of instability in the market. Since from this analysis beta value is very low, it shows there is no more instability in the market.

\section{Result and Discussions:-}

By means of analyzing Descriptive statistics from the period 2006 to 2016, In automobile sector average return for all the days of the return was calculated. It indicates that the Wednesday returns are higher than all other days of the return. In banking sector, it shows that average return of Thursday is higher than all other days of return. In finance sector, it shows that average return of Tuesday is higher than all other days of return. In FMCG sector, it shows that average return of Tuesday is higher than all other days of return. In information technology sector it shows that the Wednesday return is higher than all other days of the return. Using skewness it was examined that there is no day of the week effect in banking sector. But it shows that there is day of the week effect prevails in other days. Most commonly in all sectors Tuesdays were having variable return than all other days. In Kurtosis there is only slight flatter distribution subsistence is conformed in all sectors.

By earnings of examining from side to side correlation, association flanked by two variables can be examine. For Auto, Banking, Finance, FMCG, Media, Metal, IT results indicates that there is no correlation exists between a no significant correlation between the returns protected by Auto , Banking, Finance, FMCG, Media, Metal, IT index on a variety of days of the week., This demonstrate that present is no day of the week consequence and imply the physically powerful form of the promoter. Unite the consequences of three tackle such as expressive figures, regression, correlation, it is evidently exposed that the proceeds are not important in every one the days of the week in all seven subdivisions.

Evocative statistics powerfully poses that meticulous day return is senior than all additional existence. In correlation income of every correlated such as present is no rapport between any days of the go back with every other. From side to side regression it is investigate that the proceeds for each and every one the days of the weeks are not poles apart in 7 sectors. And chiefly on Wednesday standard on a daily basis come back is senior for automobile sector, metal \&information technology zone. By means of skewness it was investigated that there is no day of the week consequence in banking zone. But is demonstrate that present is day of the week effect keep on in additional days. Nearly everyone usually in all zones Tuesdays were having variable homecoming than all additional days. In Kurtosis in attendance is only unimportant sweet-talk allotment subsistence is conform in all zone.

\section{References:-}

1. Aharony, J. and Swary, I. (1980), "Quarterly Dividend and Earnings Announcements and Stockholders' Returns: An Empirical Analysis", Journal of Finance, Vol. 35, No. 1, pp. 1-12.

2. Allen, F. and Michaely, R. (2004), "Dividend Policy", Working Paper, Warton School Rodney L. White Center for Financial Research, University of Pennsylvania, U.S.A.

3. Asquith, P. and Mullins, D. (1983), "The Impact of Initiating Dividend Payments on Shareholders' Wealth", Journal of Business, Vol. 56, No. 1, pp. 77-96

4. Baker, M., Ruback, R. \&Wurgler, J. (2004). Behavioral Corporate Finance: A Survey. NBER Working Paper, No. W10863.

5. Barberis, N. and Thaler, R. (2004), "A Survey of Behavioral Finance", Working Paper, National Bureau of Economic Research, U.S.A.

6. Berle, A. and Means, G. (1932), The Modern Corporation and Private Property, 1st ed., Transaction Publishers.

7. Bhattacharya, S. (1979), "Imperfect Information, Dividend Policy, and the 'Bird in the Hand' Fallacy", Bell Journal of Economics, Vol. 10, pp. 259-270

8. Brav, A., Graham, J., Harvey, C., Campell, R., and Michaely, R. (2004), "Managerial Response to the May 2003 Dividend Tax Cut", Financial Management, Vol. 37, No. 4, pp. 611-624.

9. Comment, R. and Jarrell, G. (1991), "The Relative Signaling Power of Dutch-Auction and Fixed-Price SelfTenders Offers and Open-Market Share Repurchases", Journal of Finance, Vol. 46, pp. 1243-1271. 
10. DeBondt, W. and Thaler, R. (1985), "Does the Stock Market Overreact?", Journal of Finance, Vol. 40, No. 3, pp. 793-808.

11. Easterbrook, F. (1984), "Two Agency-Cost Explanations of Dividends", The American Economic Review, Vol. 74, pp. 650-659.

12. Fama, E., Jensen, M. Fisher, L. and Roll, R. (1969), "The Adjustment of Stock Prices to New Information", International Economic Review, Vol. 10, No. 1, pp. 1-21.

13. Gordon, M. (1961), The Investment, Financing, and Valuation of a Corporation, Richard D. Irwin.

14. Gordon, M. (1962), "The Savings, Investment, and Valuation of a Corporation", Review of Economics and Statistics, Vol. 44, pp. 37-51.

15. Ikenberry, D., Lakonishok, J., and Vermaelen, T. (1995), "Market Under reaction to Open Market Share Repurchases", Journal of Financial Economics, Vol. 39, pp. 181-208.

16. Jensen, M. (1986), "Agency Costs of Free Cash Flow, Corporate Finance, and Takeovers", American Economic Review, Vol. 76, No. 2, pp. 323-329.

17. Lease, R., Lewellen, W., and Schlarbaum, G. (1976), "Market Segmentation: Evidence on Individual Investor", Financial Analysts Journal, Vol. 32, pp. 53-60.

18. Miller, M. and Modigliani, F. (1961), "Dividend Policy, Growth, and the Valuation of Shares", Journal of Business, Vol. 34, pp. 235-264.

19. Miller, M. and Rock, K. (1985), "Dividend Policy under Asymmetric Information", Journal of Finance, Vol. 40, pp. 1031-1051.

20. Petit, R. (1972), "Dividend Announcements, Security Performance, and Capital Market Efficiency", Journal of Finance, Vol. 27, No. 5, pp. 993-1007.

21. Rozeff, M. (1982), "Growth, Beta and Agency Costs as Determinants of Dividend Payout Ratios", The Journal of Financial Research, Vol. 5, pp. 249-259. 